\title{
ДОСЛІДЖЕННЯ ЕФЕКТИВНОСТІ ПНЕВМАТИЧНОГО СЕПАРАТОРА З НАХИЛЕНИМ КАНАЛОМ НА ПІДГОТОВЦІ ПОСІВНОГО МАТЕРІАЛУ САФЛОРУ
}

\author{
Микола Бакум, к. т. н., Микола Крекот, к. т. н., Магомед Абдуєв, к. т. н., \\ Анатолій Михайлов, к. т. н., Марія Майборода, к. е. н., Ольга Чалая, к. с.-г. н., \\ Валентина Безпалько, к. с.-г. н., Ольга Сінясва, ст. викл., Анатолій Горбаньов, к. с.-г. н., \\ Олександр Вотченко, інж., Андрій Кузьоменський \\ Державний біотехнологічний університет, \\ вул. Алчевських, 44, м. Харків, Київський р-н, Харківська обл., Україна, \\ e-mail:kafedrashm@gmail.com
}

https://doi.org/10.31734/agroengineering2021.25.028

Бакум М., Крекот М., Абдусв М., Михайлов А., Майборода М., Чалая О., Безпалько В., Сінясва О., Горбаньов А., Вотченко О., Кузьоменський А. Дослідження ефективності пневматичного сепаратора 3 нахиленим каналом на підготовці посівного матеріалу сафлору

У статті наведені результати перевірки впливу виповненості насіння на врожайність сафлору. Вихідним матеріалом для дослідження була насіннєва суміш сафлору сорту Лагідний. Вихідна суміш містила 92,7 \% насіння сафлору, $5,14 \%$ становили легкі домішки, 0,43 \% - насіння інших культурних рослин, $1,42 \%$ - насіння бур'янів і $0,31 \%$ мінеральні домішки. Енергія проростання насіння основної культури становила 61,73 \%, а його схожість - 65,24 \%. Сортування виконували на пневматичному сепараторі з нахиленим каналом. На сепараторі отримали чотири фракції.

Найбільш виповнене насіння потрапило до першої фракції і становило 38,52 \% від маси вихідного матеріалу, до другої фракції відсортувалось 22,46 \%, до третьої - $16,53 \%$, а до четвертої - 22,49\%.

Польові дослідження проводили у 2021 році в умовах навчально-дослідного поля кафедри агротехнологій та екології на базі НДП «Центральне» Харківського національного технічного університету сільського господарства ім. Петра Василенка. Повторність дворазова, розміщення ділянок рандомізоване. Облікова площа дослідної ділянки $-25 \mathrm{~m}^{2}$. Попередник - чорний пар.

У польовому досліді вивчали ріст, розвиток та продуктивність сафлору.

За всіма показниками найкращими були рослини, отримані з насіння, що відсортувалося до першої фракції. Так, кількість кошиків цих рослин була на 35,85 \% більшою від кількості кошиків рослин, отриманих із насіння другої фракції, і на 140 \% - рослин третьої фракції. Розмір кошиків і кількість насіння з однієї рослини першої фракції теж найбільші і становлять відповідно 3,1 мм і 117,7 шт. Насіння, отримане з рослин першої фракції, - найбільш повноцінне і має масу 1000 насінин 47 г.

Ключові слова: насіння сафлору, посівний матеріал, сортування, виповненість насіння, пневматичний сепаратор, польові дослідження.

Bakum M., Krekot M., Abduiev M., Mykhailov A., Maiboroda M., Chalaia O., Bezpalko V., Siniaieva O., Horbaniov A., Votchenko O., Kuziomenskyi A. Study of the efficiency of a pneumatic separator with an inclined channel on the preparation of safflor seed material

Safflower is an oil seed. Safflower was imported to Ukraine in the second half of the 18th century. It was mainly grown in small areas of the southern arid regions.

The article presents the results of the study of impact of the safflower seed fullness on its yield. A seed mixture of safflower of Lahidnyi variety was taken as the initial material for the study. The mateeial was grown in the experimental field of KhNTUSG in 2020 . The initial mixture included $92.7 \%$ of safflower seeds, $5.14 \%$ of light impurities, $0.43 \%$ of seeds of other cultivated plants, $1.42 \%$ of weed seeds and $0.31 \%$ of mineral impurities. The germination energy of the seeds of the main crop was $61.73 \%$ and its germination was $65.24 \%$. Sorting was performed on a pneumatic separator with an inclined channel. After purification on a separator, four fractions were obtained. 
The best filled seeds were sorted to the first fraction and accounted for $38.52 \%$ by weight of the source material, $22.46 \%$ was sorted to the second fraction, $16.53 \%$ - to the third, and $22.49 \%$ - to the fourth one.

The field research was conducted in 2021 in the educational and research field of the Department of Agrotechnology and Ecology on the basis of SRF "Central" of Kharkiv Petro Vasylenko National Technical University of Agriculture. The repetition was double, the placement of plots was randomized. The area of the experimental plot was $25 \mathrm{~m}^{2}$. It was preceeded by black fallow.

The growth, development and productivity of safflower were studied in the field experiment.

In general, the best plants were obtained from seeds that were sorted to the first fraction. Thus, the number of baskets was by $35.85 \%$ more than the baskets of plants obtained from seeds of the second fraction and by $140 \%$ as compared to the plants of the third fraction. The size of the baskets and the number of seeds from one plant of the first fraction were also the largest and acoounted for $3.1 \mathrm{~mm}$ and 117.7 pcs respectively. Seeds obtained from plants of the first fraction were the fullest and the weight of 1000 seeds was $47 \mathrm{~g}$.

Seeds of the second fraction provided quite worthy indicators of safflower production. Seeds of the third and especially the fourth fraction were more expedient to be used for other purposes.

Key words: safflower seeds, seed material, sorting, fullness of seeds, pneumatic separator, field research.

Постановка проблеми. Сафлор красильний, або американський шафран, дикий шафран (Cárthamus tinctórius), - однорічна рослина родини айстрових.

Сафлор є олійною культурою, батьківщиною якої $є$ Ефіопія й Афганістан. 3 давніх часів його намагались вирощувати в різних частинах Африки та Євразії.

До України сафлор завезений у другій половині XVIII ст. Переважно вирощувався на невеликих ділянках південних посушливих регіонів. Квітки та олія сафлору включені до ряду зарубіжних фармакопей.

Сафлор - посухостійка рослина, добре пристосована до сухого континентального клімату, а його сходи витримують до $-4 \square$ нетривалих заморозків. Сафлор запилюється як перехресним способом комахами, i особливо бджолами, так i самозапилюється. Його рослини не вимогливі до грунтів і можуть вирощуватись у зонах ризикованого землеробства [14].

Врожай сафлору збирають серійними зернозбиральними комбайнами, а технологія післязбиральної обробки врожаю, і особливо підготовка посівного матеріалу для масового виробництва, не відпрацьована повною мірою [4].

Аналіз останніх досліджень і публікацій. Сучасний клімат характеризується частими та аномальними змінами зі стійкою тенденцією до постійного росту середньорічних температур, що негативно впливає на врожайність більшості сільськогосподарських культур. У цьому сафлор вигідно відрізняється від традиційних для України олійних культур $[6 ; 10 ; 12 ; 16]$. Окрім того, сафлор не боїться заморозків, а це дає змогу виконувати його посів у ранні строки, що дозволяє більш ефективно використовувати запаси грунтової вологи й отримувати високі врожаї. Але це часто перешкоджає виконанню повного комплексу робіт щодо підготовки грунту до сівби, що призводить до зростання засміченості як посівів, так і зернової частини врожаю після його збирання $[2 ; 6]$.

Аналіз технологій вирощування та засміченості зернової частини зібраного врожаю показує, що вміст насіння бур'янів у зерновій масі несталий для різних посівних площ як за видом бур'янів, так і за їхньою кількістю. Основними видами бур'янів для зібраного врожаю $є$ ті, які $\epsilon$ характерними для певних полів і залишилися після вирощування попередньої культури.

Таким чином, ранні посіви гарантують підвищення врожайності сафлору, але при цьому зростає засміченість зернової частини врожаю, що ускладнює його післязбиральну обробку. Крім того, посушливий клімат призводить до формування неповноцінного (порожнього) насіння сафлору, що ще більше ускладнює підготовку посівного матеріалу. Масове виробництво сафлору як в Україні, так і на території більшості східноєвропейських держав не набуло поширення. Тому й технології післязбиральної обробки розроблені не повною мірою. Практика виробництва сафлору в окремих господарствах показує, що післязбиральну обробку як зернової частини, так і посівного матеріалу виконують традиційними способами 3 використанням технологічних ліній, агрегатів і комплексів, призначених для післязбиральної обробки зернових культур $[8 ; 13]$.

Водночас проводяться дослідження використання нових способів та нових технічних засобів 3 обгрунтуванням параметрів процесу сепарації попереднього обробітку зернової частини врожаю [5] 3 максимальним відокремленням у відходові фракції незернової частини врожаю для створення сприятливих умов проведенню основної очистки іншими сепарувальними засобами.

Попередні дослідження використання решітних сепараторів на підготовці посівного матеріалу сафлору 3 перевіркою посівних особли- 
востей відсортованих фракцій у польових умовах показали високу їх ефективність на додатковому сортуванні 3 виділенням у відходові фракції як найкрупнішого, так і дрібного насіння основної культури $[4 ; 11 ; 13 ; 15]$.

Високу ефективність на додатковому сортуванні посівного матеріалу сафлору показало використання віброфрикційного сепаратора 3 неперфорованими робочими поверхнями [3; 7].

Незважаючи на отримані високі результати виконаних досліджень, проблема підготовки високоякісного посівного матеріалу загалом не вирішена і потребує подальшої розробки як способів, так і засобів сепарації.

Постановка завдання. Наше завдання виявити закономірності формування продуктивності насіння сафлору, підготовленого на пневматичному сепараторі з нахиленим сепарувальним каналом.

Виклад основного матеріалу. Дослідження проводили на насіннєвій суміші сафлору сорту Лагідний, вирощеного на дослідному полі ХНТУСГ у 2020 p.

Вихідна суміш містила 92,7\% насіння сафлору від маси суміші, 5,14 \% становили легкі домішки (часточки стебел різних розмірів та кусочки кошиків), $0,43 \%$ - насіння інших культурних рослин, $1,42 \%$ - насіння бур'янів (щириця, лобода, мишій, пирій тощо) і 0,31\% мінеральні домішки (грудочки грунту). Енергія проростання насіння основної культури становила лише $61,73 \%$, а його схожість - 65,24 \%.

Можливість підвищення посівних якостей цільової фракції сафлору досліджували на пневматичному сепараторі з нахиленим сепарувальним каналом. Конструктивна схема сепаратора наведена на рисунку. Сепаратор складається 3 вентиляторної установки і нахиленого повітряного каналу, які з'єднані між собою.

До вентиляторної установки входить вентилятор високого тиску 13 вхідним патрубком 2 , який приводиться в рух електродвигуном через пасову передачу. До вихідного патрубка вентилятора прикріплена проставка 4, в якій встановлено вертикальні жалюзі 3 для вирівнювання швидкості повітряного потоку в поперечному напрямі проставки. На виході проставка має розміри, які відповідають розмірам нахиленого каналу. У проставці 4 розташований механізм регулювання швидкості повітряного потоку по висоті каналу (див. рис., б), який виконаний з набору поворотних пластин 5, закріплених жорстко на осях 29, що проходять через осьові лінї боковин 30 проставки, причому осі закріплені паралельно нижній (верхній) стінці проставки. Положення кожної пластини 5 (кут $\beta$ іiі нахилу відносно поздовжньої осі каналу) можна регулювати окремо, повертаючи відповідні осі 29. Фіксація положення всіх пластин виконується одночасно притискними пластинами 28.

Нахилений повітряний канал складається зі сепарувальної камери 6, у нижній частині якої розміщені чотири приймачі 19, 20, 21 і 23 продуктів розділення. Перегородки 14 між 20 і 21 приймачами, а також 15 між 19 і 20 приймачами виконані поворотними, що дає змогу регулювати вміст приймачів. У нижній частині приймачів встановлено заслінки і мішкотримачі, які дозволяють закріплювати мішки для збирання продуктів розділення кожного приймача окремо.

До верхньої стінки сепарувальної камери 6 шарнірно закріплений живильник із циліндричною щіткою 8 і рухомою боковиною 9. До живильника приєднаний бункер 11, який у нижній частині має регулювальну заслінку 10 .

До сепарувальної камери 6 прикріплюється інерційний пиловідокремлювач 16 з осаджувальною камерою 17, яка закінчується фільтрувальним пилозбірником 18 із тканини (мішковини).

Регулювання швидкості повітряного потоку в сепарувальній камері 6 виконується зміною іiі ширини, переміщенням ділильника 13 за допомогою регулювальних гвинтів 26, закріплених в опорах 27 штурвалами 25. Ділильник 13 еластичним напрямником 24 з'єднується 3 вихідним патрубком вентилятора 1.

Вихідний матеріал сафлору 3 бункера 11 циліндричною щіткою 8 живильника подається в нахилений повітряний канал 6 рівномірно по всій його ширині. Інтенсивний повітряний потік у верхній частині каналу (швидкість повітря більша критичної швидкості переважної більшості компонентів вихідного матеріалу) має велику транспортувальну здатність, за рахунок чого швидко «розвантажується» зона каналу біля завантажувального вікна. Причому більшість легких домішок із великим коефіцієнтом вітрильності відділяється у верхній частині каналу і транспортується також уздовж верхньої частини каналу (вони не можуть опуститися, оскільки максимальна швидкість повітряного потоку $\epsilon$ дещо нижче верхньої стінки каналу через опір стінок каналу, див. вигляд епюри 22 швидкостей повітря по висоті каналу) аж в осаджувальну камеру 17. Важчі компоненти вихідного матеріалу 3 меншими коефіцієнтами вітрильності інтенсивно транспортуються за більшої швидкості повітря, 
яку мають дещо нижчі шари повітряного потоку. Ці шари повітряного потоку остаточно видувають легші домішки, які 3 якихось причин не відділилися повітряним потоком на вищих відрізках повітряного каналу. Важчі компоненти під дією гравітаційних сил рухаються по криволінійних траєкторіях і потрапляють у нижню частину каналу, де повітряний потік помірніший. У таких умовах (спокійніших) компоненти матеріалу мають змогу повніше проявити свої аеродинамічні властивості, точніше розділитися за їх різницею і надходять у приймачі 19, 20, 21, 23 продуктів розділення. Співвідношення мас компонентів у цих приймачах, а отже, і якість розділення, чи сортування, можна регулювати поворотом перегородок 14 i 15. Важкі домішки (грудочки грунту, камінці, металеві включення тощо) потрапляють до приймача 23.
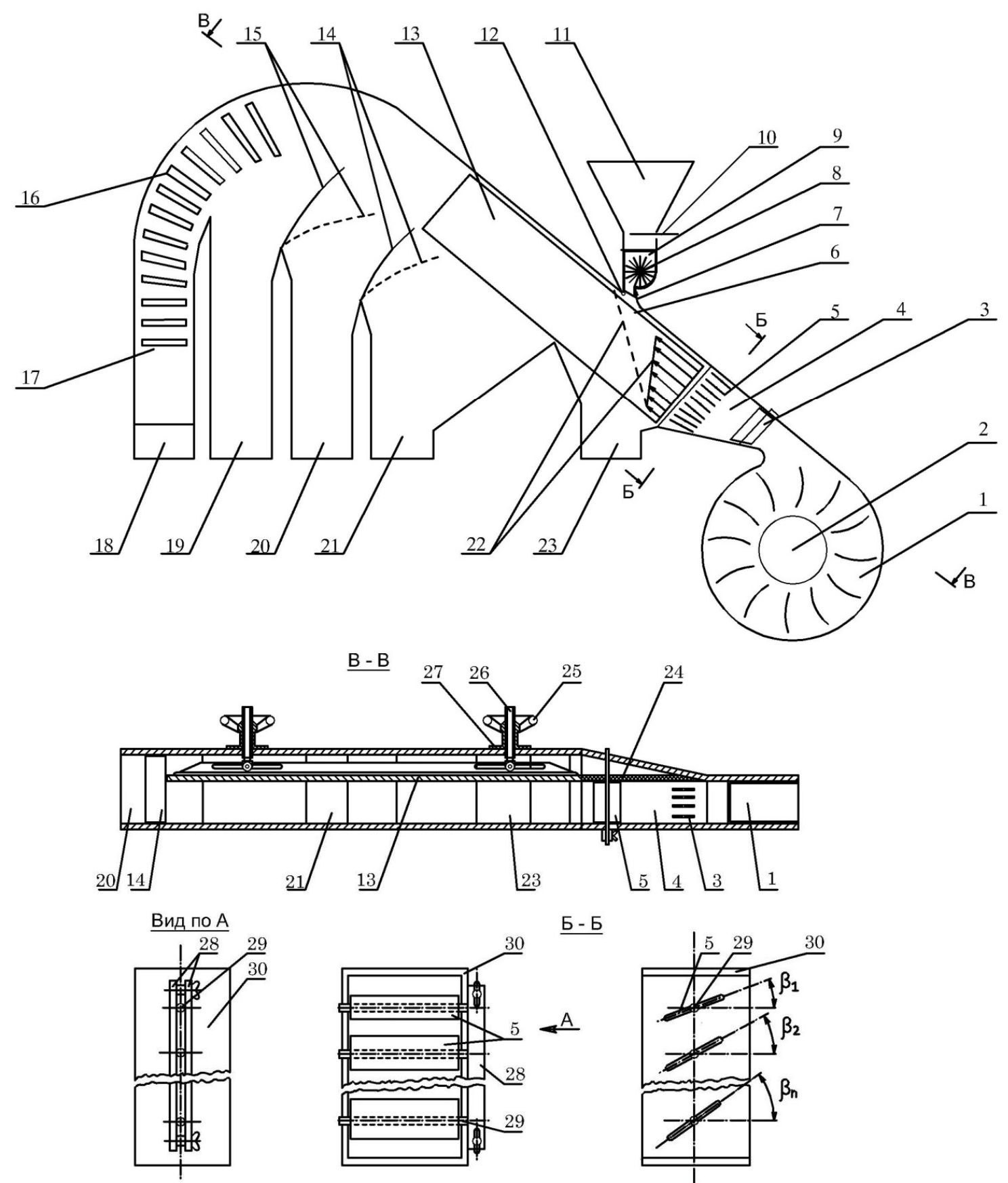

Рис. Конструктивна схема пневматичного сепаратора 3 нахиленим повітряним каналом Fig. Structural diagram of a pneumatic separator with an inclined air channel 
Легкі домішки і пил з осаджувальної камери 17 потрапляють у фільтрувальний пилозбірник 18 , який виконано в дослідному зразку з мішковини.

Результати сортування насіннєвої суміші сафлору наведено в табл. 1.

Компоненти насіннєвої суміші розділилися на чотири фракції. Найбільш повноцінне насіння сафлору відокремилося до першого i другого приймачів. Уміст першого приймача становив 38,52 \% від загальної маси вихідного матеріалу, включав насіння основної культури - 98,14 \%, що на 5,44 \% більше, ніж у вихідній суміші. Причому схожість і енергія проростання насіння сафлору цієї фракції найвищі і становлять відповідно 84,42 і 89,69\%. До другої фракції виділилося 22,46 \% маси вихідного матеріалу, причому вміст насіння основної культури в цій фракції на $0,37 \%$ вищий, ніж у першій фракції, і становить 98,41 \%. Його посівні властивості дещо нижчі від показників першої фракції: енергія проростання насіння сафлору становить 74,18 \%, а схожість - 78,29\%, що більш ніж на $10 \%$ перевищує показники вихідного матеріалу. Третя фракція за об'ємом найменша і становить 16,53 \% від маси вихідної суміші. Показники посівних якостей насіння сафлору цієї фракції є на рівні вихідного матеріалу, але маса 1000 насінин основної культури на 10,27 г менша, ніж у насіння вихідного матеріалу. Матеріал, який виділився до четвертого приймача, за всіма якісними показниками значно поступається показникам насіння, що виділилося до інших фракцій.
Третя фракція за масою лише на 5,21\% менша від другої фракції, а за якісними показниками набагато гірша від перших двох. Так, уміст насіння основної культури в ній становить лише $37,52 \%$ від загальної маси, що у 2,21 раза менше від вмісту другої фракції і навіть на 19,04 \% менше від його вмісту у вихідному матеріалі. Крім того, слід зазначити, що саме насіння сафлору менш виповнене, його маса 1000 шт. становить лише 21,70 г, що на 16,06 г менше від маси в другій фракції, майже у два рази (1,89 раза) менше від маси в першій фракції і аж на 6,83 г менше від маси 1000 насінин сафлору у вихідному матеріалі.

Переважну більшість третьої фракції становлять легкі домішки (60,75 \% від маси фракції). Також у цю фракцію відокремились частина пошкодженого насіння інших культурних рослин $(0,73 \%$ від маси фракції) і повноцінне насіння бур'янів в оболонках (1,0% від маси фракції).

Уміст четвертої фракції найменший i становить лише $12,15 \%$ від маси вихідного матеріалу. У ній насіння сафлору становить лише $18,55 \%$ від загальної маси, причому саме насіння дрібне за розмірами, а маса 1000 насінин становить лише 16,13 г, що на 12,40 г менше порівняно з насінням вихідного матеріалу.

Основну частину цієї фракції становлять легкі домішки (77,03 \%). До неї також виділилось щупле, подрібнене насіння інших культурних рослин $(0,44 \%$ від маси фракції) і насіння бур'янів в оболонках $(3,98 \%)$.

Таблиця 1. Результати підготовки посівного матеріалу сафлору на пневматичному сепараторі

Table 1. The results of preparation of safflower seed on a pneumatic separator

\begin{tabular}{|l|c|c|c|c|c|}
\hline \multirow{2}{*}{ Показник } & \multicolumn{5}{c|}{ Фракція } \\
\cline { 2 - 6 } & $\begin{array}{c}\text { Вихідний } \\
\text { матеріал }\end{array}$ & 1 & 2 & 3 & 4 \\
\hline Розподіл насіннєвого матеріалу за фракціями, \% & 100 & 38,52 & 22,46 & 16,53 & 22,49 \\
\hline Вміст насіння основної культури, \% & 92,70 & 98,14 & 98,41 & 85,95 & 82,64 \\
\hline Вміст легких домішок, \% & 5,14 & 0,21 & 0,27 & 12,61 & 12,95 \\
\hline Вміст насіння інших культурних рослин, \% & 0,43 & 0,51 & 0,59 & 0,42 & 0,14 \\
\hline Вміст насіння бур'янів, \% & 1,42 & 0,57 & 0,33 & 1,02 & 4,26 \\
\hline Вміст мінеральних домішок, \% & 0,31 & 0,57 & 0,40 & 0 & 0 \\
\hline Маса 1000 насінин сафлору, г & 30,43 & 41,98 & 38,47 & 20,15 & 10,17 \\
\hline Енергія проростання насіння сафлору, \% & 61,73 & 84,42 & 74,18 & 61,17 & 10,84 \\
\hline Схожість насіння сафлору, \% & 65,24 & 89,69 & 78,29 & 62,11 & 12,63 \\
\hline
\end{tabular}


Дуже схожою на четверту фракцію за гранулометричним складом $\epsilon$ п'ята фракція, яка становить за масою $19,76 \%$ від загальної маси вихідного матеріалу. Насіння основної культури в ній лише 16,16\%, причому маса його 1000 шт. становить лише 10,51 г, що у 2,71 раза менше порівняно 3 масою насіння вихідної суміші, i, очевидно, ця фракція для сівби цінності не має.

Для оцінки здатності пневматичного сепаратора сортувати насіння сафлору за посівними якостями дослідили енергію проростання $\mathrm{i}$ схожість насіння основної культури кожної фракції. Із табл. 1 видно, що в перші два приймачі відокремилось насіння сафлору більш повноцінне, його енергія проростання становить відповідно 67 i $61 \%$, що майже в 1,5 раза перевищує таку в насіння вихідного матеріалу. Схожість теж найвища у двох перших приймачах - відповідно 72 і $67 \%$. Посівні показники останніх трьох фракцій дуже низькі і як посівний матеріал це насіння цінності не має.

Таким чином, аналіз результатів первинної сепарації на пневматичному сепараторі 3 нахиленим повітряним каналом насіннєвої суміші сафлору, отриманої за збирання врожаю прямим комбайнуванням, показав, що жодна 3 отриманих п'яти фракцій не відповідає вимогам до посівного матеріалу.

Зважаючи на велику засміченість останніх трьох фракцій та низьку якість насіння сафлору в них, подальше доочищення цих насіннєвих сумішей малоефективне.

Уміст перших двох приймачів загалом становить 53,57 \% маси вихідного матеріалу. Така об'єднана насіннєва суміш містить 85,24 \% насіння основної культури, що на 28,68 \% більше, ніж у вихідного матеріалу. Саме насіння сафлору в об'єднаній фракції має масу 1000 насінин 39,84 г, що на 11,31 г більше від маси насіння вихідної суміші. Енергія проростання і схожість насіння підвищились відповідно на 23 і $24 \%$ і дорівнюють 65 і $70 \%$. У цьому насіннєвому матеріалі легких домішок зменшилось майже в 7 разів, що покращує як умови тимчасового його зберігання, так і умови подальшого доочищення на інших насіннєочисних машинах.

Польові дослідження проводили у 2021 р. в умовах навчально-дослідного поля кафедри агротехнологій та екології на базі НДП «Центральне» ХНТУСГ. Об'єктом дослідження були відсортовані фракції насіннєвого матеріалу сафлору районованого сорту Лагідний. Закладення дослідів проводили з дотриманням вимог наукової агрономії. Повторність дворазова, розміщення ділянок рандомізоване. Облікова площа дослідної ділянки $-25 \mathrm{~m}^{2}$. Попередник - чорний пар.

У польовому досліді вивчали ріст, розвиток та продуктивність сафлору залежно від виповненості насіння, відсортованого за аеродинамічними властивостями на чотири фракції (табл. 2) пневматичним сепаратором.

Таблиця 2. Морфологічні показники рослин сафлору залежно від фракції посівного матеріалу

Table 2. Morphological parameters of safflower plants depending on the seed fraction

\begin{tabular}{|c|c|c|c|c|}
\hline Фракція насіння & Висота рослин, см & $\begin{array}{c}\text { Товщина стебла, } \\
\text { мм }\end{array}$ & $\begin{array}{c}\text { Висота закладки перших } \\
\text { бічних пагонів, см }\end{array}$ & $\begin{array}{c}\text { Довжина } \\
\text { кореня, см }\end{array}$ \\
\hline I & 100,9 & 5,9 & 64,0 & 13,1 \\
\hline II & 101,8 & 6,4 & 59,2 & 13,5 \\
\hline III & 80,1 & 6,9 & 58,8 & 14,8 \\
\hline IV & 0 & 0 & 0 & 0 \\
\hline
\end{tabular}

Польові дослідження проводили відповідно до загальноприйнятих методик [7; 9].

У польових дослідах реєстрували основні фази вегетації рослин: сходи, формування кошиків, цвітіння, дозрівання. Проведенням замірів при повному настанні фаз вегетації визначали динаміку росту рослин. Продуктивність сафлору за варіантами визначали відбором проб рослин 3 $1 \mathrm{~m}^{2}$ кожного повторення для кожного варіанта. Насіння висівали вручну 3 міжряддям 45 см за температури грунту $4,3 \ldots 4,8^{\circ} \mathrm{C}$ без внесення мінеральних добрив. Під час визначення врожайності враховували густоту продуктивного стеблостою, середню масу зерна з однієї рослини.

До збирання врожаю 3 ділянок визначали середню кількість рослин сафлору на $1 \mathrm{~m}^{2}$ кожної дослідної ділянки. Цей показник для перших трьох фракцій змінювався в обмеженому діапазоні від 61 рослини на ділянках, засіяних насінням першої фракції, до 56 - насінням третьої фракції, а продуктивних рослин - відповідно 58, 44 рослини. Слід зазначити, що 3 насіння, яке відсортувалося до четвертої фракції, у польових умовах не з'явилися сходи на ділянках жодної повторності. 
Проведені дослідження 3 вивчення впливу виповненості насіння, відсортованого пневматичним сепаратором, на продуктивні показники сафлору показали, що виповненість насіння впливає як на морфологічні показники рослин у процесі розвитку, так і на показники структури врожаю. У польових дослідженнях тривалість вегетаційного періоду від повних сходів до повної стиглості для всіх фракцій насіння була однакова i становила 116 діб.

На початковому етапі польових досліджень морфологічних показників рослин сафлору, отриманих із відсортованого насіння перших трьох фракцій, особливих відмінностей не виявлено. Але за подальшого вегетаційного розвитку спостерігалося відставання росту в посівах, отриманих із насіння, відсортованого до третьої фракції (менш виповненого). Висота рослин третьої фракції у фазі повної стиглості становила лише $80,1 \mathrm{~cm}$, що на понад 20 см менше порівняно 3 висотою рослин із насіння попередньої фракції. Висота закладки перших бічних пагонів у цих рослин теж найменша $(58,8$ см), а довжина коренів найбільша.

Польовими дослідженнями також встановлено, що виповненість насіння, відсортованого за аеродинамічними властивостями, впливає на структурні показники посівів, у тому числі на кількість кошиків на одній рослині, їх діаметр і кількість насіння з однієї рослини та масу його 1000 шт. (табл. 3).

За цими показниками найкращими були рослини, отримані з насіння, що відсортувалося до першої фракції. Так, кількість кошиків була на $35,85 \%$ більшою від кількості кошиків рослин, отриманих із насіння другої фракції, і на 140 \% від рослин третьої фракції. Розмір кошиків і кількість насіння 3 однієї рослини першої фракції теж найбільші і становлять відповідно 3,1 мм i 117,7 шт. Насіння, отримане 3 рослин першої фракції, найбільш повноцінне і має масу 1000 насінин 47 г.

Таблиця 3. Структура врожаю та врожайність сафлору в умовах досліду

Table 3. Yield structure and safflower yield under experimental conditions

\begin{tabular}{|c|c|c|c|c|c|c|c|}
\hline \multirow[t]{2}{*}{$\begin{array}{l}\text { Фракція } \\
\text { насіння }\end{array}$} & \multirow{2}{*}{$\begin{array}{c}\text { Кількість } \\
\text { кошиків на } 1 \\
\text { рослині, шт. }\end{array}$} & \multirow{2}{*}{$\begin{array}{c}\text { Діаметр } \\
\text { кошиків, } \\
\text { см }\end{array}$} & \multirow{2}{*}{$\begin{array}{c}\text { Кількість } \\
\text { насіння } 31 \\
\text { рослини, шт. }\end{array}$} & \multirow[t]{2}{*}{$\begin{array}{l}\text { Маса } 1000 \\
\text { насінин, Г }\end{array}$} & \multicolumn{2}{|c|}{$\begin{array}{c}\text { Кількість рослин на } 1 \text { м², } \\
\text { шт. }\end{array}$} & \multirow{2}{*}{$\begin{array}{c}\text { Біологічна } \\
\text { врожайність, } \\
\text { ц/га }\end{array}$} \\
\hline & & & & & всього & продуктивних & \\
\hline I & 7,2 & 3,1 & 117,7 & 117,7 & 61 & 58 & 32,08 \\
\hline II & 5,3 & 2,7 & 109,9 & 109,9 & 60 & 56 & 28,74 \\
\hline III & 3 & 2,6 & 80,3 & 80,3 & 56 & 44 & 14,98 \\
\hline IV & 0 & 0 & 0 & 0 & 0 & 0 & 0 \\
\hline
\end{tabular}

Висновки. Для перевірки впливу виповненості насіння на врожайність сафлору відсортовано на пневматичному сепараторі чотири фракції. Найбільш виповнене насіння потрапило до першої фракції і становило 38,52\% від маси вихідного матеріалу, до другої фракції відсортувалось $22,46 \%$, до третьої - $16,53 \%$, а до четвертої - 22,49\%.

Враховуючи показники росту і розвитку, структури врожаю та врожайності, отримані за вирощування насіння сафлору фракцій різної виповненості, можна зробити висновок, що для сівби найбільш повноцінним $є$ насіння, відсортоване до першої фракції, яке забезпечує найвищий показник врожайності.

Цілком достойні показники виробництва сафлору забезпечує висів насіння другої фракції. Насіння третьої, а особливо четвертої, фракції доцільніше використовувати для інших цілей.
Насіння середніх розмірів мало найбільший показник врожайності за достатньо високих показників росту і продуктивних якостей та найкращий показник виживання рослин.

\section{Бібліографічний список}

1. Бакум М. В., Крекот М. М., Абдуєв М. М., Майборода М. М. Результати виробничих випробувань пневматичного сепаратора на додатковому сортуванні насіння гороху. Вісник ХНТУСГ ім. П. Василенка. 2019. Вип. 198. С. 74-77.

2. Доочищення та сортування насіння сафлору на віброфрикційному сепараторі / М. В. Бакум та ін. Вісник ХНТУСГ ім. П. Василенка. 2019. Вип. 198. С. 12-17.

3. Дослідна справа в агрономії: навч. посіб.: у 2 кн. Кн. 1: Теоретичні аспекти дослідної справи / А. О. Рожков та ін.; за ред. А. О. Рожкова. Харків: Майдан, 2016. 316 c.

4. Дринча В. М. Исследование сепарации семян и разработка машинных технологий их подготовки. Воронеж: НПО «Модек», 2006. 384 с. 
5. Заїка П. М. Теорія сільськогосподарських машин. Харків: Око, 2006. Т. 3. 408 с.

6. Методика наукових досліджень в агрономії: навч. посіб. / В. Г. Дідора та ін. Київ: Центр навч. літ., 2013. $264 \mathrm{c}$.

7. Обгрунтування ефективності використання решітних сепараторів для підготовки посівного матеріалу сафлору / М. В. Бакум та ін. Вісник ХНТУСГ ім. П. Василенка. 2019. Вип. 198. С. 18-25.

8. Ушкаренко В. О. Вирощування сафлору красильного на півдні України: практичні рекомендації / під ред. П. Н. Лазера. Херсон: ПП «ЛТ-Офіс», 2012. 28 с.

9. Філіпов С. Г. Агротехнічні прийоми на економічну ефективність вирощування сафлору красильного в умовах зрошення півдня України. Вісник аграрної науки Причорномор'я. 2014. Вип. 2. С. 143-149.

10. Харченко С. О. Апробація розроблених решіт 3 активаторами у виробничих умовах. Матеріали наук.практ. конф. викладачів, аспірантів та студентів. Суми: НАУ, 2017. Т. 3. С. 68.

11. Харченко С. О. Теорія процесів просіювання зернових сумішей на віброрешетах зерноочисних машин. Цілі сталого розвитку третього тисячоліття: матеріали Міжнар. наук.-практ. конф., 23-25 трав. 2018 р. Київ: НУБіП, 2018. Т. 5. С. 249-253.

12. Effect of growth stage based irrigation on soil water extraction and water use efficiency of spring safflower cultivars / Sukhbir Singh et al. Agricultural Water Management. 2016. Vol. 177. P. 432-439. doi: 10.1016/j.agwat.2016.08.023.

13. Elnaz Ebrahimian, Seyyed Mohammad Seyyedi, Ahmad Bybordi, Christos A. Damalas. Seed yield and oil quality of sunflower, safflower, and sesame under different levels of irrigation water availability. Agricultural Water Management. 2019. Vol. 218. P. 149-157. doi: 10.1016/j.agwat.2019.03.031.

14. Intensification of sifting of flat grain on sieves of grain-cleaning machines / S. Kharchenko et al. INMATENAgicultural Engineering. 2018. № 3, vol. 56. P. 39-56.

15. Mohammad Hossein Shahrokhnia, Ali Reza Sepaskhah. Physiologic and agronomic traits in safflower under various irrigation strategies, planting methods and nitrogen fertilization. Industrial Crops and Products. 2017. Vol. 95. P. 126-139. doi: 10.1016/j.indcrop.2016.10.021.

16. Overview of the Oilseed Safflower (Carthamus tinctorius L.). Encyclopedia of Food Grains (Second Edition). 2016. Vol. 1. P. 254-258. doi: 10.1016/B978-012-394437-5.00030-9.

Стаття надійшла 29.08.2021 